\title{
Decomposition of air pollution emissions from Swedish manufacturing
}

\author{
Polina Ustyuzhanina ${ }^{1,2}$ (D
}

Received: 20 April 2021 / Accepted: 3 July 2021 / Published online: 19 August 2021

(c) The Author(s) 2021

\begin{abstract}
Starting from the '90s, Swedish manufacturing output has been constantly growing, while emissions of some major air pollutants have been declining. This paper decomposes manufacturing pollution emissions to identify the forces associated with the abatement. It uses a newly available dataset on actual annual emissions from Swedish manufacturing and creates an index of emission intensities for the major local air pollutants to directly estimate the technique effect for the period 20072017. The results suggest that the main driver of the clean-up was improvements in emission intensities, while the composition of output actually moved towards more pollution-intensive goods. In the absence of changes in scale and technique, manufacturing pollution emissions would have increased in a range between 3 (particulate matter) and 20\% (non-methane volatile compounds) between 2007 and 2017.
\end{abstract}

Keywords Environmental policy $\cdot$ Pollution decomposition · Technique effect · Composition effect · Manufacturing

JEL Classification Q53 - Q56

\begin{abstract}
I thank Rob Hart, Shon Ferguson, Hildegunn Kyvik Nordås, Rikard Forslid and two anonymous referees. This research strongly benefited from their comments and suggestions. I am thankful for the insightful feedback received from participants at the 2020 Stockholm-Uppsala Doctoral Student Workshop in Economics as well internal workshops at the Department of Economics at Swedish University of Agricultural Sciences. I declare that there is no conflict of interests. The paper is not funded by any external funding.
\end{abstract}

Polina Ustyuzhanina

polina.ustyuzhanina@slu.se

1 Department of Economics, Swedish University of Agricultural Sciences, P.O. Box 7070, 75007 Uppsala, Sweden

2 Research Institute of Industrial Economics (IFN), P.O. Box 55665, 10215 Stockholm, Sweden 


\section{Introduction}

Emissions of air pollutants such as sulphur dioxide $\left(\mathrm{SO}_{2}\right)$, nitrogen oxides $\left(\mathrm{NO}_{\mathrm{x}}\right)$, non-methane volatile compounds (VOCs), and particulate matter $\left(\mathrm{PM}_{10}\right)$ from manufacturing have fallen steeply in North America and Western and Northern Europe over recent decades (Levinson 2009; Brunel 2017; Shapiro and Walker 2018; Najjar and Cherniwchan 2020). As our lives are directly affected by the air we breathepollution has serious negative effects on both human health and productivity and labour supply (Graff Zivin and Neidell 2013; WHO 2018)-understanding the sources of the abatement is crucial to ensure that a pollution decline would continue in a sustainable way. While the sources of the abatement might be due to trade liberalization or increasing demand for cleaner goods, there is a wealth of evidence that the primary driver of these emission reductions in industrialised economies has been technique effects, i.e. production processes have become cleaner, which overwhelms the positive scale effect of increasing overall economic activity. However, there is much less clarity about the role of the composition effect, i.e. the effect of changes in the range of goods produced. Hitherto, evidence on composition effects has been mixed and inconclusive. For environmental policy targeting such ambitious goals as $50 \%$ share of renewable energy sources in inland energy consumption by $2020,50 \%$ decrease in energy intensity by 2030 compared to the year 2005, or zero net greenhouse gas emissions by $2045^{1}$, it is important to be aware of the strengths of both composition and technique effects and the underlying mechanisms. For instance, research subsidies leading to energy-efficiency improvements and lower emissions may lower prices of energy-intensive goods, which risks leading to a countervailing composition effect.

The goal of this study is to examine the main drivers of a decline in air pollution emissions from Swedish manufacturing between the years 2007 and 2017. For this, I use detailed data on manufacturing emissions to air and decompose them into three mechanisms: scale, composition, and technique effects. Taking Grossman and Krueger (1993) and Copeland and Taylor (1994) as the starting point and following the decomposition approach as in Levinson $(2009,2015)$, I create an index of emissions intensities for $\mathrm{SO}_{2}, \mathrm{NO}_{\mathrm{x}}, \mathrm{VOCs}$ and $\mathrm{PM}_{10}$ - analogous to a Laspeyres and Paasche price indexes - to explore the contribution of these three effects to the emission reductions in Swedish manufacturing during the period 2007-2017.

The focus on manufacturing is due to several reasons. Historically, the sector has been an important driver of the Swedish economy. In the recent decade, almost one-third of total sales and one-fourth of gross value-added came solely from manufacturing production. At the same time, many manufacturing activities are energyand pollution-intensive. Between 2007 and 2017, the sector alone accounted for almost $40 \%$ of total $\mathrm{SO}_{2}$ emissions in Sweden on average. Although the contribution

\footnotetext{
1 All targets are set for Sweden. Sources: Sweden's Climate Act and Climate Policy Framework, https:// www.swedishepa.se/Environmental-objectives-and-cooperation/Swedish-environmental-work/Workareas/Climate/Climate-Act-and-Climate-policy-framework-/; Sweden's energy and climate goals, https:// www.energimyndigheten.se/klimat--miljo/sveriges-energi--och-klimatmal/.
} 
of $\mathrm{NO}_{\mathrm{x}}$, VOCs and $\mathrm{PM}_{10}$ from manufacturing to the aggregate emissions is modest ( $14 \%$ on average during the studied period), the reductions in emissions were remarkably high $-30 \%$ on average, larger than for agriculture or other industrial sectors. Being pollution-intensive, the manufacturing sector is directly targeted by environmental policies that aim at improving energy efficiency, increasing the share of renewables in energy consumption and reducing industrial emissions, where among the most important are the EU legislation on industrial emissions ${ }^{2}$ and the Swedish Environmental code. In a small open economy as Sweden, manufacturers, which are often exporters of both final and intermediate goods and owned by multinational corporations, are largely exposed to competition in the world market and sensitive to unexpected price changes (Tillväxtverket 2018). Manufacturing producers should both comply with stringent environmental regulations and be competitive. By quantifying the scale, composition and technique effects, one can better understand how the manufacturing sector as a whole responded to these different forces.

The study relates to two strands of literature. First, the paper contributes to a growing empirical literature examining the sources of the emission reductions, mainly in the manufacturing sector, with the method of statistical decomposition (Grether et al. 2009; Levinson 2009, 2015; Brunel 2017; Shapiro and Walker 2018; Cole and Zhang 2019; Najjar and Cherniwchan 2020). I contribute to the literature by applying and adapting the state-of-the-art methodology and very recent data disaggregated at the four-digit level to a small open economy, Sweden. Regarding the methodology, for my measure of manufacturing output, I use data on the value of manufacturing production, which excludes costs for goods that were bought and resold without being adjusted. A more common approach in this literature-to use sales as a measure of output (Levinson 2009, 2015; Cole and Zhang 2019; Najjar and Cherniwchan 2020)_would leave out the importance of trade for a small open economy such as Sweden. Regarding data, I study actual annual emissions for Swedish manufacturing during a very recent period, 2007-2017. It allows me to estimate the technique effect directly, as opposed to early studies (Levinson 2009; Brunel 2017) where it is calculated as a residual. Finally, I complement the literature with additional evidence on the presence of a brown shift - a persistent shift towards more dirty production, which offsets a clean-up of manufacturing.

Second, the paper relates to a large empirical literature examining the relationship between environmental policies of different character and industry- or firmlevel environmental outcomes (e.g., Greenstone 2003; Millock and Nauges 2006; Gamper-Rabindran 2009; Gibson 2019; Najjar and Cherniwchan 2020), and to few papers examining some particular policy instruments in Sweden (Sterner and Turnheim 2009; Åström et al. 2017). While these papers focus on evaluating specific policies, often establishing a causal link between a change in regulation and environmental performance, the goal of my paper is to examine how the manufacturing

\footnotetext{
${ }^{2}$ EU Directive 2010/75/EU and its precursor Directive 2008/1/EC. Following the regulation, plants performing certain industrial activities are required to obtain a production permit that is based on the use of best available techniques. Producers that fail to comply will be subject to penalties.
} 
sector in Sweden evolved - in terms of production and air pollution emissions-during the very recent period, 2007-2017, when various regulations were in place. ${ }^{3}$

The main finding of the paper is that the composition of the Swedish manufacturing sector switched towards pollution-intensive goods between the years 2007 and 2017. I show that holding both scale and technique effect constant, emissions of $\mathrm{SO}_{2}$ and VOCs would increase by 7 and $20 \%$, respectively. At the same time, the results indicate that, as expected, the clean-up of Swedish manufacturing appears to be primarily driven as elsewhere by the technique effect. For example, a fall in $\mathrm{SO}_{2}$ and $\mathrm{PM}_{10}$ emissions by 34 and 48 per cent corresponds to a decrease in the emissions intensity by 39 and $25 \%$, respectively. Also, the findings suggest that the role of the composition and technique effects might differ in terms of sign and magnitude both across the most pollution-intensive manufacturing industries and pollutants.

The rest of this paper proceeds as follows. Section 2 describes the relevant literature and discusses the possible sources of the brown shift. In Sect. 3, I describe the data sources and the decomposition method. The results of the decomposition analysis are in Sect. 4. Section 5 discusses the robustness of the findings, and Sect. 6 concludes.

\section{Literature review and motivation}

In this section, I review two strands of the existing literature to which I contribute in this paper. First, I discuss the relevant empirical studies examining the relationship between various environmental policies and industry- or firm-level environmental outcomes. Mainly, for the manufacturing sector. Second, I review the literature that employs the same decomposition method as in this paper. Also, I discuss the importance of the higher data disaggregation and possible mechanisms that might explain positive (i.e., pollution-increasing) compositional changes that were found in some recent studies.

\subsection{Environmental policies and environmental outcomes}

As the paper examines changes in manufacturing emissions during the period when several regulations that target industrial emissions to the air have been implemented or were already in place, it is important to understand the potential of environmental policies with a similar design to reduce both emissions and emission intensities and how industries at the aggregate level or firms might react to such regulations.

There is a wealth of evidence that regulations setting emissions standards for the major air pollutants leads to lower emissions. For instance, it has been shown that the US Clean Air Act (CAA), which is probably one of the most studied

\footnotetext{
3 Apart from the aforementioned legislation on industrial emissions, the EU directives on national ceilings to reduce air pollution, the EU Emissions Trading System (ETS), the Swedish $\mathrm{SO}_{2} \operatorname{tax}$ and $\mathrm{NO}_{\mathrm{x}}$ charge are some other important environmental regulations and instruments that were in place between 2007 and 2017. See also Sect. A.4 in the Appendix.
} 
environmental policies, is a powerful tool in reductions of Ozone, $\mathrm{SO}_{2}$ and $\mathrm{PM}_{10}$ emissions (e.g., Henderson 1996; Greenstone 2003; Gamper-Rabindran 2009; Gibson 2019). To mention some examples, Gamper-Rabindran (2009) shows that emissions of VOCs from the chemical industry decreased by $21 \%$ in $1988-2001$; Gibson (2019) finds that $\mathrm{PM}_{10}$ from manufacturing plants fell by between 33 and $38 \%$ relative to non-regulated plants between 1992 and 2014. However, the adaptation to a more stringent environmental regulation does not necessarily go through adopting cleaner technologies. Instead, an environmental policy can encourage manufacturing producers to reallocate dirty production to less regulated territories or to substitute air emissions with water emissions. In the case of the CAA, almost one-fourth of reductions in $\mathrm{PM}_{10}$ was eliminated by such leakage. Another possible mechanism that might explain the reduction in aggregate emissions-a decline in manufacturing output and exit of dirty producers. A policy might lead to overall improvements in emission intensities, while at the same time forcing producers to decrease production, rather than encouraging them to adopt "green" technologies. Najjar and Cherniwchan (2020) find that a decline in manufacturing $\mathrm{PM}_{2.5}$ emissions, caused by a comprehensive air pollution regulation in Canada in 2004-2010, was primarily due to a decrease in production, rather than technological improvements. ${ }^{4}$

Another policy instrument that might have a positive effect on both reduction in emissions and emission intensities is an environmental tax. Two such taxes have been in place in Sweden for almost three decades now: $\mathrm{SO}_{2} \operatorname{tax}$, which is based on the sulphur content of fuels during combustion, and $\mathrm{NO}_{\mathrm{x}}$ charge combined with refund payments, applied to all boilers that produce energy above a certain annual threshold. Surprisingly, very few papers look at the role of such instruments in encouraging manufacturers to pollute less and abate more. Sterner and Turnheim (2009) show that the Swedish $\mathrm{NO}_{\mathrm{x}}$ tax with refund system pushes plants to abate but they do not provide any evidence on the effect on emissions. Aström et al. (2017) look jointly at multiple $\mathrm{SO}_{2}$ policy instruments between 1990 and 2012 and find that limiting the sulphur content in fuel was associated with lower $\mathrm{SO}_{2}$ emissions but the paper does not provide a direct estimate of the tax's effectiveness. In general, a shift to fuels with lower sulphur content has been considered as a major driver in $\mathrm{SO}_{2}$ reductions in the industrial processes in Sweden (Naturvårdsverket 2015). ${ }^{5}$ In the French context, the tax on air pollutants $\left(\mathrm{SO}_{2}\right.$ and VOCs are among them) was associated with lower pollution levels in the chemical, coke and iron and steel industries between 1990 and 1998 (Millock and Nauges 2006) but the particular mechanisms of these reductions are not evaluated.

I add to this large heterogeneous literature by providing descriptive evidence of how the manufacturing sector taking as a whole developed-in terms of its

\footnotetext{
4 The evaluation of this policy is of particular interest as its design is very similar to the EU's policies on industrial emissions that were in place during the studied period in my paper.

5 Several papers find that under the EU ETS firms switched to a "greener" type of fuel, for example, from coal and oil to gas (Ellerman and McGuinness 2008; Wagner et al. 2014). Although the EU ETS targets $\mathrm{CO}_{2}$ emissions and these studies do not provide evidence for emissions of local pollutants, there might be spillover effects. For example, shifting to another type of fuel to cut on $\mathrm{CO}_{2}$ emissions might also reduce emissions of $\mathrm{SO}_{2}$ or VOCs.
} 
production and air pollution emissions-when multiple environmental policies were in place.

\subsection{Sources of emission reductions in manufacturing}

My paper contributes to a growing empirical literature examining the sources of the emission reductions in the manufacturing sector. In particular, it complements the literature employing a statistical decomposition method to examine changes in air emissions and emission intensities. This strand of literature has as its starting point the idea that changes in pollution emissions over time can be decomposed into three channels: scale, composition, or technique effects (Grossman and Krueger 1993; Copeland and Taylor 1994). That is, a decline in emissions can be due to a decrease in production (scale), changes in the production structure towards cleaner goods (composition), or improvements in emission intensities (technique). In the last decade, the Levinson approach (Levinson 2009, 2015) that relies on creating an index of emission intensities similar to the Laspeyres or Paasche index has been widely implemented in the environment-related context in empirical studies with industrial data at different levels of aggregation. Overall, the main conclusion is that manufacturing production becomes clear, despite output growth. In the United States, manufacturing emissions of major regulated air pollutants- $\mathrm{SO}_{2}, \mathrm{NO}_{\mathrm{x}}, \mathrm{VOCs}$, and PM-fell by more than 50\% during the period 1990-2008 (Levinson 2015; Shapiro and Walker 2018). Within the EU, manufacturing emissions of $\mathrm{SO}_{2}$ decreased by almost 60 percent and $\mathrm{NO}_{2}$ and VOCs emissions-by approximately 25 percent between 1995 and 2008 (Brunel 2017). In Canada, $\mathrm{NO}_{\mathrm{x}}, \mathrm{CO}$, VOCs and $\mathrm{PM}_{2.5}$ emission intensities from manufacturing fell by between 41 and $70 \%$ during the period 1992-2005 (Najjar and Cherniwchan 2020). A similar pattern has been observed even outside of North America and the EU. Grether et al. (2009) find that aggregate emissions of $\mathrm{SO}_{2}$ from manufacturing in more than 60 countries fell by $10 \%$ in the '90s, despite an increase in production. ${ }^{6}$ In China, $\mathrm{SO}_{2}$ emissions from manufacturing increased by 51 percent, while the sector grew by more than 600 percent between 2003 and 2015 (Cole and Zhang 2019). I add to this literature by providing empirical evidence for such a small open economy as Sweden where the manufacturing sector is exposed to competition in the world market, sensitive to unexpected price changes and should comply with various environmental regulations.

In recent years, the methodology has also been applied to greenhouse gas emissions (LaPlue and Erickson 2020; Rottner and von Graevenitz 2021; Brunel and Levinson 2021). Overall, they find that the technique effect plays a major role in the reductions of carbon emissions. ${ }^{7}$

As recognized in this literature, the level of sectoral disaggregation in data is crucial. A higher level of aggregation would assign within-industry changes in

\footnotetext{
${ }^{6}$ Grether et al. (2009) use a slightly different decomposition method.

7 Löfgren and Muller (2010) do an accounting exercise for Swedish $\mathrm{CO}_{2}$ emissions for the period 19932006 but use another methodology. They find that fuel substitution was an important driver in reducing aggregate carbon emissions for the industrial and business sectors.
} 
composition to the technique effect. When more aggregated data is used composition effects are likely to be missed. In the extreme case, when there is only one large manufacturing sector it would not be possible to pin down any changes in the compositional mix at all. Thus, to quantify both composition and technique effects most accurately, it is important to build the analysis on the data that takes into account heterogeneity in emission intensities across smaller sub-industries within larger industries. ${ }^{8}$ Environment-related data at lower levels of aggregation are scarce as it is often not collected or monitored directly, but estimated and reported at the national or sectoral levels (Naturvårdsverket 2015). For these reasons, for example, Levinson (2009) and Brunel (2017) use US emission intensities for one single year, 1987, and calculate the technique effect as a residual. Because I use detailed data on actual emission intensities, in addition to taking us closer to the "true" values of the composition and technique effects, it allows estimating the technique effect directly.

\subsection{Why can the brown shift occur?}

In a partial-equilibrium framework, Copeland and Taylor (2005) showed that if pollution reductions are policy-driven, then the more stringent environmental policy would affect emissions not only through cleaner techniques but also through a compositional shift towards cleaner goods, i.e., both effects are negative. However, from the aforementioned studies à la Levinson (2009), the results regarding technique and composition effects for air pollutants are contrasting: technique effects are large and negative, whereas composition effects are generally small. In some cases, composition moves towards less polluting goods, but only to a limited extent (see, e.g., Grether et al. 2009; Shapiro and Walker 2018; Najjar and Cherniwchan 2020). In other cases, composition effects are found to increase emissions (see, e.g., Brunel 2017; Cole and Zhang 2019). A positive composition effect—or a brown shift, a shift towards more dirty production-might be present in $\mathrm{CO}_{2}$ emissions, too. Barrows and Ollivier (2018) find that Indian manufacturers moved towards more dirty products between 1991 and 2010: firms became dirtier overall, even though the technique effect at the industry level was negative.

What are the mechanisms that might explain the brown shift? Regarding the technique effect, it is more and more clear that this is driven by improved technology rather than, for instance, offshoring of pollution. The pollution haven (or pollution offshoring) hypothesis links decisions made by firms in pollution-intensive industries to trade with countries that have weaker environmental regulations (or to outsource dirty intermediate inputs from such countries) due to trade liberalization. However, empirical investigations have delivered little or no support for this idea (Grossman and Krueger 1993; Kahn 2003; Levinson and Taylor 2008; Cave and Blomquist 2008; Brunel 2017; see also Cherniwchan et al. (2017) for an overview). My analysis adds to this evidence by showing that the share of the

\footnotetext{
${ }^{8}$ Recently, several authors have developed and applied pollution decomposition at the firm-, plant, and product-level. See Martin (2011), Cherniwchan et al. (2017), Barrows and Ollivier (2018), Shapiro and Walker (2018).
} 
pollution-intensive industries in the total value of manufacturing output increased over time and, therefore, pollution offshoring was unlikely to be a problem for the Swedish manufacturing sector between 2007 and 2017.

A possible explanation for the brown shift is the presence of strategic environmental policies, i.e., countries may deliberately skew environmental policy to favour certain pollution-intensive industries (Barrett 1994; Ulph and Ulph 1996; Greaker 2003). That might be the case for some protectionistic policy decisions in the European Union (e.g., Miravete et al. (2018)) but there is no reason to expect systematic changes in one specific direction. If policy pushes consumers towards clean goods, the brown shift might be driven either by exogenous (non-policy) reductions in the price of dirty goods causing substitution towards such goods, or by income effects, i.e. that household demand shifts towards pollution-intensive goods such as large and powerful cars and passenger air travel as incomes increase, as suggested by Hart (2018). More evidence on this question could be found if we studied changes in the relative prices of dirty and clean goods, as well as quantities.

To sum up, the findings from the empirical literature on the effects of environmental regulations imposing air quality standards suggest that such policies might lead to lower aggregate emissions but not necessarily to lower emission intensities at the firm- or plant-level. They might also encourage abatement-for instance, to switch to another type of fuel. At the industry level, a clean-up in manufacturing emissions is often driven by improvements in emission intensities but the role of compositional changes is ambiguous. Importantly, the estimated magnitude of both technique and composition effects depends on the level of disaggregation in datathe more detailed data takes us closer to the "true" values of both technique and composition effects.

\section{Methods and data}

To decompose manufacturing emissions and study the potential sources of the manufacturing abatement, I take as my starting point Grossman and Krueger (1993) and Copeland and Taylor (1994) and follow Levinson (2009, 2015). In this section, I briefly describe the methodology, data sources and the main issues that might arise.

\subsection{Decomposition of pollution emissions}

The approach is based on the idea that changes in total pollution might be assigned to three mechanisms: changes in the overall size of the economy (scale effect), changes in the mix of sectors-from towards less pollution-intensive industries (composition effect), and changes in emission intensities of individual industries created by changes in the technologies used in production and abatement (technique effect). Put formally, the total amount of pollution from manufacturing, denoted by $P$, can be written as 


$$
P=\sum_{i} p_{i}=V \sum_{i} \frac{v_{i}}{V} \frac{p_{i}}{v_{i}}=V \sum_{i} \theta_{i} z_{i}
$$

where $i=1, \ldots, n$ indexes manufacturing industries, $V$ is the total manufacturing output, $\theta_{i}$ is each industry's share in total output $\left(\theta_{i}=v_{i} / V\right)$, and $z_{i}$ is each industry's emissions coefficient measured as the amount of pollution per monetary value of output in industry $i\left(z_{i}=p_{i} / v_{i}\right)$. That is, total manufacturing pollution, $P$, equals the sum of pollution from each manufacturing industry, $p_{i}$. Alternatively, manufacturing pollution can be written as the total value of produced manufacturing output, multiplied by the sum of a product of each industry's share in total output, $\theta_{i}$, and its emission intensity, $z_{i}$.

In vector notation, Eq. (1) takes form

$$
P=V \boldsymbol{\theta}^{\prime} z
$$

where $\theta$ and $z$ are $n \times 1$ vectors containing the output shares of each of $n$ industries and their emissions intensities, respectively.

Totally differentiate equation (2) to obtain

$$
d P=\boldsymbol{\theta}^{\prime} z d V+V z^{\prime} d \boldsymbol{\theta}+V \boldsymbol{\theta}^{\prime} d z .
$$

When the total pollution is decomposed as given in (3), the three terms on the righthand side have a nice interpretation as three main channels, or effects, that determine the change in the total pollution over time $(d P)$ : scale, composition and technique effects.

\subsection{Data}

To estimate how much of change in the total pollution over time can be attributed to each of the effects in (3), I need four time series: (1) data on manufacturing emissions for one or several air pollutants, $P$; (2) gross value of output from manufacturing, $V$; (3) each industry's contribution to output, $\theta_{i}$; (4) each industry's emission intensities, $z_{i}$.

I rely on two main data sources. First, data on each four-digit industry's contribution to the total manufacturing output is taken from Statistics Sweden. As a measure of output, I use the variable "Production value", which is a sum of net sales, other operating income and changes in inventory, excluding costs for goods that are bought and sold without being processed. I adjust for inflation using the sector-specific producer price index (PPI) from Statistics Sweden. Second, to calculate each industry's emission intensities and the total emissions of $\mathrm{SO}_{2}, \mathrm{NO}_{\mathrm{x}}, \mathrm{PM}_{10}$ and non-methane $\mathrm{VOCs}^{9}$, I use data on actual annual emissions from the newly-available Swedish Pollutant Release and Transfer Register (PRTR). Originally, the data is reported at the plant-level which I aggregate to the four-digit level to combine with

\footnotetext{
9 In the Appendix, there are also results for $\mathrm{CO}_{2}$ available, although emissions of greenhouse gases are outside of the scope of this paper.
} 
data on manufacturing output. The study covers the period from 2007 to 2017 and includes the whole manufacturing sector.

To my knowledge, data from the Swedish PRTR has not previously been used in economic studies. The facilities listed in the Swedish PRTR are those that perform activities that (1) require environmental permits under the Ordinance (1998:899) concerning Environmentally Hazardous Activities and Protection of Public Health, or (2) covered by the EU Regulation 166/2006 on the European PRTR. ${ }^{10}$ The Swedish PRTR includes emissions both to air and water and applies to more than 70 chemicals. Currently, there are more than 7000 facilities that have to report their emissions to the PRTR. The reporting thresholds for the pollutants included in this study are given in Table A.5. The data on pollution emissions at the four-digit level is aggregated from emissions reported by 431 manufacturing plants. Although the register includes only a small share of Swedish firms, the reporting thresholds were set in such a way that the register would cover at least $90 \%$ of the total mass emissions for each specific pollutant (Skårman et al. 2019). The reporting threshold is an important limitation of the data: it allows calculating emission intensities for the most pollution-intensive four-digit industries but those industries that are relatively clean are represented poorly in the PRTR. To evaluate PRTR accuracy, I compare it to data on air pollution emissions from manufacturing at the two-digit level. The data is obtained from the Air Environmental Accounts (AEA) and administrated by Statistics Sweden. Air pollution data in the AEA is a combination of collected and estimated emissions, and it is reported at the national and sectoral levels (Naturvårdsverket 2015). Although these two datasets do differ in values of aggregate emissions, the correlation between them, estimated as regression of log emissions from the PRTR on log emissions from the AEA controlling for year fixed effects, is close to unity for $\mathrm{SO}_{2}, \mathrm{NO}_{\mathrm{x}}$ and VOCs. ${ }^{11}$ Thus, the results for separate two-digits industries should be interpreted keeping this limitation in mind as those manufacturers that emit relatively little are underrepresented in the sample employed in this study. Another concern with the PRTR data is the fact that it is self-reported, and, therefore, there is a possibility for a measurement error. It is, however, unlikely that the error is systematic as (1) an obligation to report emission is unaffected by reported emissions, and (2) the reported emissions should be reviewed by the permitting authority. For descriptive statistics and details on data collection and data management, see the Appendix (Table 7).

Table 1 lists five most pollution-intensive four-digit industries for two of four pollutants $-\mathrm{SO}_{2}$ and $\mathrm{NO}_{\mathrm{x}}$. There is large heterogeneity in emission intensities not only across two-digit manufacturing industries but, most importantly, within each of them. For two other pollutants, VOCs and $\mathrm{PM}_{10}$, the picture is very much alike. For instance, there is a large difference between $\mathrm{SO}_{2}$ and $\mathrm{NO}_{\mathrm{x}}$ emission intensities

\footnotetext{
${ }_{10}$ In fact, the Swedish thresholds for $\mathrm{NO}_{\mathrm{x}}$ and $\mathrm{PM}_{10}$ are even lower than the thresholds in the European PRTR.

11 The estimated coefficient for $\log \left(\mathrm{SO}_{2}\right)$ is 1.609 (t-statistic $\left.=9.57\right)$, for $\log \left(\mathrm{NO}_{\mathrm{x}}\right)-1.586(5.80)$, for $\log \left(\mathrm{PM}_{10}\right)-2.381(3.76)$ and for $\log (\mathrm{VOCs})-0.961$ (6.75). The coefficients are estimated with OLS with year fixed effects and standard errors clustered at the two-digit industry level.
} 
Table 1 Top-5 pollution-intensive industries, $\mathrm{SO}_{2}$ and $\mathrm{NO}_{\mathrm{x}}$

\begin{tabular}{llllll}
\hline & $\mathrm{SO}_{2}$ & & $\mathrm{NO}_{\mathrm{x}}$ & \\
\cline { 2 - 3 } \cline { 5 - 6 } & $(1)$ & $(2)$ & & $(3)$ & $(4)$ \\
& Industry & Intensity & Industry & Intensity \\
\hline 1 & Pulp, 17.11 & 107.20 & Cement, lime, plaster, 23.51-23.52 & 634.47 \\
2 & Abrasive products, 23.91-23.99 & 44.92 & & Pulp, 17.11 & 222.54 \\
3 & Paper, 17.12 & 33.95 & & Paper, 17.12 & 119.25 \\
4 & Glass, 23.11-23.13 & 31.43 & & Glass, 23.11-23.13 & 58.93 \\
5 & Iron, steel, ferro-alloys, 24.10 & 29.55 & & Abrasive products, 23.91-23.99 & 40.84 \\
\hline
\end{tabular}

Table reports average emission intensities for $\mathrm{SO}_{2}$ and $\mathrm{NO}_{\mathrm{x}}$ in tons per bln SEK (columns 2 and 4) in descending order. The industry codes in columns 2 and 4 are given under the SNI2007 classification: "Manufacture of pulp"-17.11, "Manufacture of paper"-17.12, "Manufacture of glass" - 23.11-23.13, "Manufacture of cement, lime and plaster"-23.51-23.52, "Manufacture of abrasive products and nonmetallic mineral products"-23.91-23.99, "Manufacture of iron, steel, ferro-alloys"-24.10

of "Manufacture of pulp" and "Manufacture of paper", although both industries are parts of the same two-digit industry "Manufacture of pulp, paper and paperboard". The numbers in Table 1 highlight the importance of employing data on emissions intensities at the most disaggregated level possible to account for heterogeneity and estimate the changes in techniques and compositions more precise.

\subsection{Index issues: Laspeyres and Paasche}

Most decomposition analyses of pollution and energy use falls into two categories: index and structural decomposition analysis (IDA and SDA, respectively). While the former relies on country- or industry-level data, the latter combines it with data from input-output tables (see, e.g., Hoekstra and Van den Bergh (2003) or de Boer and Rodrigues (2020) for an overview). In this study, I employ on the IDA and use the analogues of the additive Laspeyres and Paasche indexes in the environment-related context. Both of them leave a residual term, which tends to be larger when the more aggregated data are used. Another possible decomposition approach is to use the log-mean Divisia index (LMDI). ${ }^{12}$ It is based on the concept of logarithmic change over time, while both the Laspeyres' - or Paasche's-type index measures the percentage change over time, using weights based on values in a base year. Compared to the Laspeyres'and Paasche's-type index, the LMD index does not leave a residual term. However, the caveat of the method is its sensitivity to a substantially large number of zeroes in the data. Because I use actual emissions reported by manufacturing plants that emit above the thresholds and aggregate it the level of four-digit manufacturing sub-industries, the number of zeroes in the dataset is indeed large. It

\footnotetext{
${ }^{12}$ See, for example, Ang (2004) for a methodological overview; and González et al. (2014)—for (one of many) empirical applications.
} 
makes the LMDI method less suitable for this study. As a robustness test, I do the same analysis with the LMD index and more aggregated data and find very similar qualitatively results.

The data I use allow me to directly assess the technique effect rather than indirectly project each industry's emission using fixed industry-specific values of pollution intensities as in the early studies (Levinson 2009; Brunel 2017). That is, the paper estimates the changes in emission intensities for each manufacturing industry directly on a year-by-year basis, holding its composition constant. For each pollutant, I calculate an index of emission intensity similar to a Laspeyres'- and Paasche's-type index with the individual industries' emissions instead of prices ( $I_{L}$ and $I_{P}$, respectively) as follows:

$$
\begin{gathered}
I_{L}=\frac{\sum_{i=1}^{n} z_{i}^{(t)} v_{i}^{(0)}}{\sum_{i=1}^{n} z_{i}^{(0)} v_{i}^{(0)}} \times 100 \\
I_{P}=\frac{\sum_{i=1}^{n} z_{i}^{(t)} v_{i}^{(t)}}{\sum_{i=1}^{n} z_{i}^{(0)} v_{i}^{(t)}} \times 100,
\end{gathered}
$$

where $z_{i}^{(t)}$ is emission intensity for industry $i$ in year $t, z_{i}^{(0)}$ and $v_{i}^{(0)}$ are emission intensity and output for industry $i$, respectively, in the first year.

In its traditional context with prices and quantities, the Laspeyres index is upward-biased and tends to overstate inflation, whereas the Paasche index tends to understate inflation because it uses current-period quantity weights that already reflects changes in consumption due to price changes. Similarly, in the pollution context, the Laspeyres index might overstate the technique effect, while the Paasche index might understate it due to composition changes over the period. By calculating both the Laspeyres'- and Paasche's-type index, I put bounds on the degree to which the technique effect might be over- or underestimated.

\section{Results}

I take Eqs. 4 and 5 directly to the data and present the results in this section. I find a clear brown shift for the manufacturing sector as a whole but I also show that there is vast heterogeneity across manufacturing industries.

\subsection{Results for the manufacturing sector}

Table 2 shows the Laspeyres and Paasche indexes of emission intensity for each air pollutant for the period between 2007 and 2017. These are the direct estimates of the technique effect for the Swedish manufacturing sector. The emission intensity of $\mathrm{PM}_{10}$ decreased the most compared to other pollutants. It fell to $0.527(-47.3 \%)$ of its value in the year 2007 by the Laspeyeres index or to $0.488(-51.2 \%)$ by the 
Table 2 Indexes of emission intensities, 2007-2017

\begin{tabular}{lll}
\hline Pollutant & Laspeyres & Paasche \\
\hline $\mathrm{NO}_{\mathrm{x}}$ & 0.906 & 0.842 \\
$\mathrm{PM}_{10}$ & 0.527 & 0.488 \\
$\mathrm{SO}_{2}$ & 0.625 & 0.577 \\
$\mathrm{VOCs}$ & 0.789 & 0.662 \\
\hline
\end{tabular}

Paasche index. The indexes for $\mathrm{SO}_{2}$ and VOCs fell within a similar range, while the $\mathrm{NO}_{\mathrm{x}}$ emission intensity experienced the smallest decline among all other pollutants-it decreased to 0.906 by the Laspeyres index and 0.842 by the Paasche index.

The reductions of $\mathrm{SO}_{2}$ and $\mathrm{PM}_{10}$ emission intensities appear to be the largest. The results of the decomposition into the scale, composition and technique effects are in Table 3. Figure 1 plots the decomposition for all four pollutants with the Laspeyrestype index over time (similar graphs for the Paasche index are in the Appendix).

Aggregate emissions of $\mathrm{SO}_{2}$ and $\mathrm{PM}_{10}$ decreased by 34 and $48 \%$, respectively, between 2007 and 2017, while a decline in VOCs and $\mathrm{NO}_{\mathrm{x}}$ was more modest-less than $10 \%$. As the period in the analysis includes the global financial crisis and the Great Recession, the growth in the manufacturing (inflation-adjusted) production was just below zero, $-3 \%$. For all pollutants except for VOCs, the line that depicts the technique effect declines almost as much as actual pollution towards the end of the period. In fact, for $\mathrm{PM}_{10}$ emissions, the pollution reduction is almost entirely attributed to the changes in emission intensity. For VOCs and $\mathrm{SO}_{2}$ emissions, for a large part of the studied period, the line depicting the technique effect is below the line depicting the change in aggregate pollution, indicating that, in the absence of any other effect, the overall reduction in these two air pollutants would be even larger. For instance, for $\mathrm{SO}_{2}$, it would be $37 \%$ over the period.

The most striking finding is a positive composition effect: the line that illustrates changes in composition is above the scale effect line for all four pollutants during

Table 3 Decomposition of Swedish manufacturing emissions, 2007-2017

\begin{tabular}{|c|c|c|c|c|c|c|}
\hline & \multirow{2}{*}{$\begin{array}{l}\Delta \text { Total pollution } \\
\text { (1) }\end{array}$} & \multirow{2}{*}{$\begin{array}{l}\text { Scale } \\
\text { (2) }\end{array}$} & \multicolumn{2}{|l|}{ Laspeyres } & \multicolumn{2}{|l|}{ Paasche } \\
\hline & & & $\begin{array}{l}\text { Composition } \\
\text { (3) }\end{array}$ & $\begin{array}{l}\text { Technique } \\
\text { (4) }\end{array}$ & $\begin{array}{l}\text { Composition } \\
\text { (5) }\end{array}$ & $\begin{array}{l}\text { Technique } \\
\text { (6) }\end{array}$ \\
\hline $\mathrm{NO}_{\mathrm{x}}$ & -0.069 & -0.033 & 0.058 & -0.094 & 0.122 & -0.158 \\
\hline $\mathrm{PM}_{10}$ & -0.475 & -0.033 & 0.032 & -0.473 & 0.070 & -0.512 \\
\hline $\mathrm{SO}_{2}$ & -0.338 & -0.033 & 0.070 & -0.375 & 0.118 & -0.423 \\
\hline VOCs & -0.041 & -0.033 & 0.203 & -0.211 & 0.331 & -0.338 \\
\hline
\end{tabular}

Table reports estimates from a decomposition of the change in air pollution intensity of the Swedish manufacturing sector between 2007 and 2017. The industries are defined as four-digit codes under the NACE Rev. 2 classification. Column 1 reports the percentage change in aggregate emissions from the manufacturing sector compared to the year 2007. The aggregate pollution is decomposed into the scale (column 2), composition and technique effects using the Laspeyres'-type index (columns 3 and 4) and the Paasche's-type index (columns 5 and 6). Each row reports estimates for a different air pollutant 


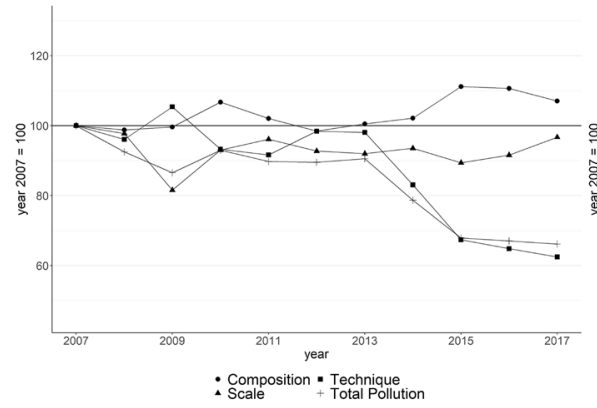

(a) $\mathrm{SO}_{2}$

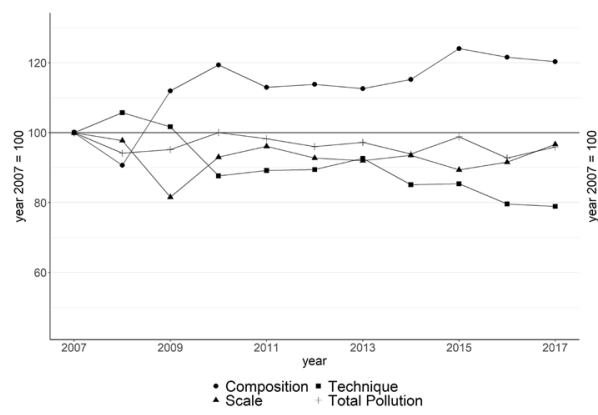

(c) VOCs

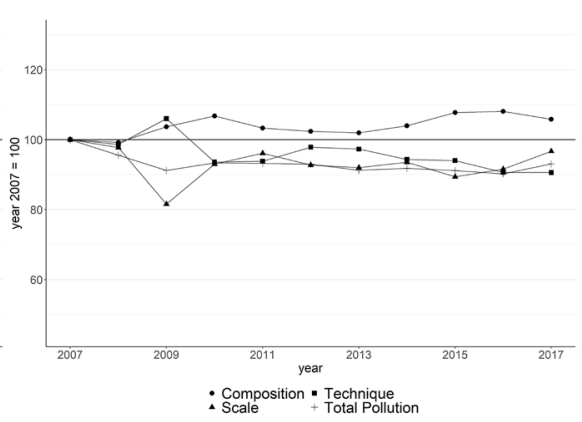

(b) $\mathrm{NO}_{\mathrm{x}}$

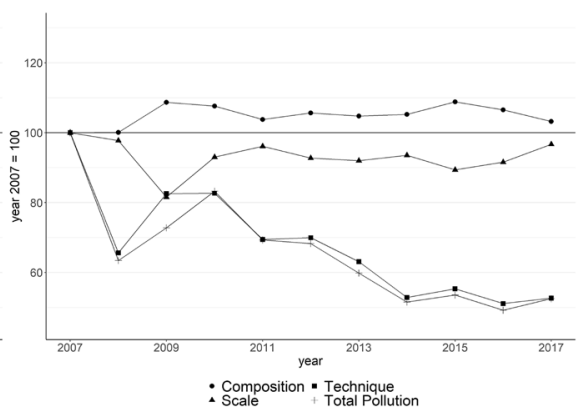

(d) $\mathrm{PM}_{10}$

Fig. 1 Decomposition of air pollution emissions from Swedish manufacturing, 2007-2017. Notes: The technique effect is calculated by taking the percentage change in a Laspeyres'-type index as in equation (4). The composition effect is calculated as the difference between the change in the aggregate pollution, the scale effect and the technique effect. Values are normalized to 100 in 2007

almost the entire period. The interpretation is simple, although unexpected: the mix of four-digit industries within the whole manufacturing sector changed in such a way that it moved towards pollution-intensive goods. Holding both scale and technique effects constant, the changes in composition alone would increase $\mathrm{SO}_{2}, \mathrm{PM}_{10}$ and $\mathrm{NO}_{\mathrm{x}}$ emissions in a range between 3 and 7\%. The largest pollution-increasing composition effect is for VOCs: in the absence of any other effect, emissions of this group of pollutants would rise by $20 \%$ compared to the level of the year 2007 . As shown in Table 3, both the Laspeyres and Paasche indexes captured the brown shift for all four pollutants.

The decomposition analysis per se does not allow for causal inference: it cannot answer what particular policy determined the changes in technique and composition of manufacturing. But with regard to the brown shift, some points are worth mentioning. First, to adjust for price fluctuations, I deflated the data using the sector-specific PPI. The positive composition effect is, therefore, not a result of price changes. Second, the results might be driven by one or several pollution-intensive industries. But the combination of a positive composition effect and negative technique effect persists even when I remove the most pollution-intensive industries (see Table 9 in the Appendix). Another concern is that I use the production value measured in monetary terms, which might over- or underestimate the real growth in produced 
quantity in a particular manufacturing industry. It is especially relevant for "Manufacture of coke and refined petroleum products". Its share doubled between 2007 and $2017 .{ }^{13}$ In fact, the increase in the volume produced in this industry was slightly volatile but modest during the period. ${ }^{14}$ However, when I drop this industry from the sample it does not affect the results qualitatively: for $\mathrm{SO}_{2}$ emissions, the technique effect is -0.347 and the composition effect is +0.061 , computed with the Laspeyres index.

\subsection{Heterogeneity within Swedish manufacturing}

The results of the decomposition summarized in Table 3 delivers an important message: the reductions of manufacturing pollution emissions were due to the pollutiondecreasing technique effect but the pollution-increasing composition effect limited the clean-up of the sector as a whole. But within the manufacturing sector, there is large heterogeneity, both in terms of the contribution of each sub-industry to the gross emissions and the sectoral output. In fact, in 2017, the share of the most pollution-intensive industries in the gross manufacturing emissions was more than $80 \%$ for all four pollutants and above $90 \%$ for $\mathrm{SO}_{2}$ and VOCs. ${ }^{15}$ But taking together, they contribute to approximately $40 \%$ of the gross manufacturing output (in 2017).

As the pollution-intensive industries contribute the most to the gross manufacturing emissions, it is worth looking closer at their technique and composition effects. These are listed in Table 4. Clearly, these industries evolved differently between 2007 and 2017-the calculated changes in emission intensities vary both in sign and in magnitude. They also differ from the technique effects calculated for the whole manufacturing sector. For instance, the technique effects for "Manufacture of paper and paper products" (NACE code 17) for $\mathrm{SO}_{2}$ and $\mathrm{PM}_{10}$ are very similar to the values from Table 3 but for $\mathrm{NO}_{\mathrm{x}}$ - the technique effect is much larger in magnitude. Furthermore, it appears that the technique effect for VOCs was positive, i.e., emission intensities of VOCs increased over time and contributed to more pollution. Similarly for "Manufacture of basic metals" (NACE code 24) - the technique effect calculated for $\mathrm{PM}_{10}$ emissions indicates no presence of technological improvements in this manufacturing industry. For $\mathrm{SO}_{2}$ and $\mathrm{NO}_{\mathrm{x}}$, it has the negative sign but the magnitude is very different: it is lower for the former and much larger for the latter. The role of the composition effect differs, too.

\footnotetext{
13 The share of the group of industries from 19.10 to 20.17 under the NACE Rev. 2 classification in the total deflated value of production increased from 0.0463 to 0.105 over the period.

14 Own calculations based on the Industrial Production Index for the sector "Manufacture of coke and refined petroleum products" from Statistics Sweden.

15 The most pollution-intensive two-digit industries are different for different pollutants. For $\mathrm{SO}_{2}$, $\mathrm{PM}_{10}$ and $\mathrm{NO}_{\mathrm{x}}$, these are "Manufacture of paper and paper products" and "Printing and reproduction of recorded media" (NACE codes 17-18), "Manufacture of other non-metallic mineral products" (NACE code 23), "Manufacture of basic metals" (NACE code 24), "Manufacture of coke and refined petroleum products", "Manufacture of chemicals and chemical products" and "Manufacture of basic pharmaceutical products and pharmaceutical preparations" (NACE codes 19-21). For VOCs, it is also "Manufacture of rubber and plastic products" (NACE code 22) and "Manufacture of motor vehicles, trailers and semitrailers" (NACE code 29).
} 
Table 4 Composition and technique effects for the most pollution-intensive industries, 2007-2017

\begin{tabular}{|c|c|c|c|c|c|c|c|c|c|}
\hline \multirow[b]{3}{*}{ Industry } & \multicolumn{4}{|l|}{$\mathrm{SO} 2$} & \multirow[b]{3}{*}{ Industry } & \multicolumn{4}{|l|}{ NOx } \\
\hline & \multicolumn{2}{|c|}{ Laspeyres } & \multicolumn{2}{|l|}{ Paasche } & & \multicolumn{2}{|c|}{ Laspeyres } & \multicolumn{2}{|l|}{ Paasche } \\
\hline & $\mathrm{CE}$ & $\mathrm{TE}$ & $\mathrm{CE}$ & $\mathrm{TE}$ & & $\mathrm{CE}$ & $\mathrm{TE}$ & $\mathrm{CE}$ & $\mathrm{TE}$ \\
\hline 17 & 0.096 & -0.360 & 0.092 & -0.356 & 17 & 0.089 & -0.045 & 0.087 & -0.043 \\
\hline $19-21$ & 0.009 & -0.570 & 0.009 & -0.570 & $19-21$ & 0.003 & -0.559 & 0.008 & -0.564 \\
\hline 23 & -0.241 & -0.578 & -0.051 & -0.768 & 23 & -0.245 & 0.292 & -0.083 & 0.130 \\
\hline \multirow[t]{3}{*}{24} & 0.044 & -0.265 & 0.036 & -0.257 & 24 & 0.009 & -0.226 & 0.006 & -0.223 \\
\hline & \multicolumn{4}{|l|}{ VOCs } & & \multicolumn{4}{|l|}{ PM10 } \\
\hline & \multicolumn{2}{|c|}{ Laspeyres } & \multicolumn{2}{|l|}{ Paasche } & & \multicolumn{2}{|c|}{ Laspeyres } & \multicolumn{2}{|l|}{ Paasche } \\
\hline Industry & $\mathrm{CE}$ & $\mathrm{TE}$ & $\mathrm{CE}$ & $\mathrm{TE}$ & Industry & $\mathrm{CE}$ & $\mathrm{TE}$ & $\mathrm{CE}$ & $\mathrm{TE}$ \\
\hline 17 & 0.080 & 0.049 & 0.081 & 0.049 & 17 & 0.092 & -0.479 & 0.090 & -0.477 \\
\hline $19-21$ & -0.052 & -0.584 & -0.040 & -0.596 & $19-21$ & 0.009 & -0.925 & -0.414 & -0.925 \\
\hline 22 & -0.229 & 0.648 & 0.041 & 0.378 & 23 & 0.257 & -0.471 & 0.285 & -0.498 \\
\hline 29 & -0.004 & -0.150 & -0.004 & -0.150 & 24 & -0.073 & 0.211 & -0.070 & 0.209 \\
\hline
\end{tabular}

Table reports estimates of the composition effect (CE) and technique effect (TE) for the most pollutionintensive industries. The estimates are for the period 2007-2017. The industries are defined as two-digit codes under the NACE Rev. 2 classification. The industries are included based on the average pollution intensity over the period 2007-2017

For instance, while it was pollution-increasing for all pollutants, the negative sign prevails for VOCs emissions from the dirties two-digit industries.

The results for the year-by-year decomposition for two-digit industries are also ambiguous and differ both across pollutants and in comparison to the findings for the whole manufacturing sector. For sake of brevity, I focus on only one pollutant, $\mathrm{NO}_{\mathrm{x}}$, and two large groups of two-digit industries - the paper and pulp industry (NACE code 17) and petroleum, chemical and pharmaceutical industries (NACE codes 19-21). Unfortunately, the values of output at the four-digit level are reported by Statistics Sweden in a way that does not allow looking at time series for industries 19, 20 and 21 separately. All three effects are calculated as in Eqs. 3-5 but evaluated within a particular two-digit industry (or group of industries) rather than for the whole manufacturing sector. The decomposition of $\mathrm{NO}_{\mathrm{x}}$ emissions from these two large groups of industries are plotted in Fig. 2. While the whole manufacturing sector showed a slightly negative growth between 2007 and 2017 and production in the paper and pulp industry fell by $10 \%$ (panel (a)), the scale effect for the petroleum, chemical and pharmaceutical industries (panel (b)) was very large and positive. Holding changes in techniques and compositions constant, $\mathrm{NO}_{\mathrm{x}}$ emissions would have increased by almost $50 \%$ compared to the year 2007 . The growth was mainly in the petroleum industry when the value of output more than doubled over the studied period. Two other effects have also completely different patterns. Similar to the whole sector, these industries became cleaner, and the technique effect contributed to the clean-up. But the role of the reductions in emissions to the overall decline in $\mathrm{NO}_{\mathrm{x}}$ emission intensities was very different. For the paper and pulp industry, both the technique and scale effects were pollution-decreasing but the 


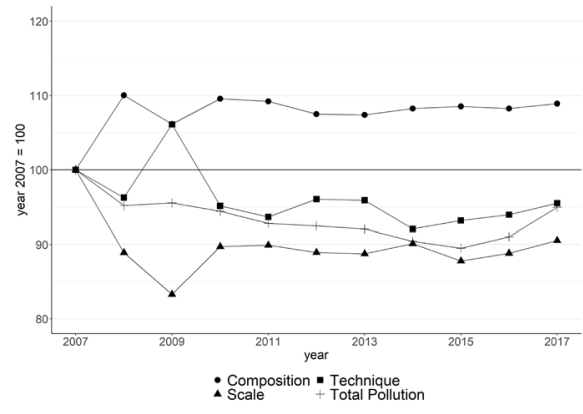

(a) Paper and pulp industry

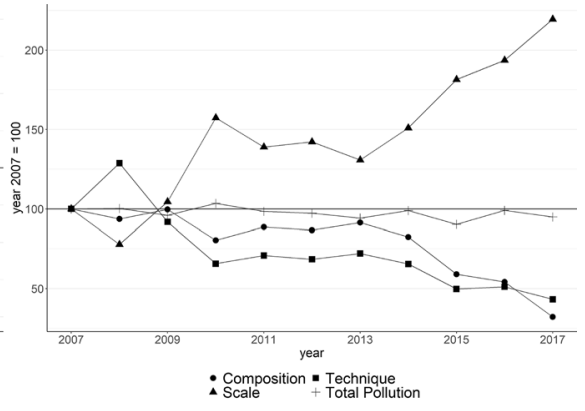

(b) Petroleum and chemical industries

Fig. 2 Decomposition of $\mathrm{NO}_{\mathrm{x}}$ emissions for two-digit industries, 2007-2017. Notes: Panel (a) shows the decomposition for the industry 17 under the NACE Rev. 2 classification. Panel (b) shows the decomposition for the group of two-digit industries 19-21 under the NACE Rev. 2 classification. The technique effect is calculated by taking the percentage change in a Laspeyres'-type index as in equation (4). The composition effect is calculated as the difference between the change in the aggregate pollution, the scale effect and the technique effect. Values are normalized to 100 in 2007

negative output growth played a more important role. Furthermore, their contribution to $\mathrm{NO}_{\mathrm{x}}$ reductions was offset by changes in the mix of four-digit sub-industries towards more dirty production. There was a constant brown shift starting after the global financial crisis. In the absence of the scale and technique effects, $\mathrm{NO}_{\mathrm{x}}$ emissions would have increased by $9 \%$. For the chemical and pharmaceutical industries, changes in the mix of sub-industries were less important but changes in $\mathrm{NO}_{\mathrm{x}}$ emissions from increasing due to substantial output growth.

There might be various sources of variation across two-digit industries. Among others, these industries use very different production technologies and, hence, might not necessarily react in the same way to the same policy. Identifying particular policy mechanisms is outside the scope of this paper. The goal of this exercise is to emphasize that heterogeneity within the manufacturing sector is substantial. Despite a tendency to raise the costs of dirty industries to push producers towards cleaner technologies within both Sweden and the EU, the results for the technique effect for the most pollution-intensive industries are ambiguous and differ across pollutants. While for the sector as a whole the technique effect was the major driver of the reductions in emissions, its role seems to be less important in the clean-up of some specific two-digit industries. The same applies to the brown shift. Also, this exercise highlights the importance of using the most detailed data available to improve the precision of the estimates of changes in compositions and techniques.

\section{Robustness and discussion}

Although the methodology this study uses has been widely implemented in other environment-related economic studies, it is not without limitations. I discuss its drawbacks in the section below and do several robustness checks to test the sensitivity of the results. 
The method I use does not account for the fact that each four-digit industry consists of smaller heterogeneous sub-industries and each of them consists of even more heterogeneous firms and plants. Over time, the composition at a higher level of disaggregation may change, and there may be some new entries or exits. In the framework used in this study, these changes are assigned to the technique effect, which is an important limitation of the analysis.

The analysis suggests that decomposition based on the more aggregated data may leave out a large proportion of compositional changes. Table 5 shows the results of the same decomposition analysis but using data on both pollution emissions and (real) output aggregated at the two-digit level: a higher level of aggregation tends to assign withinindustry changes in composition to the technique effect and a bigger share of changes in composition is likely to be missed. Therefore, a higher level of disaggregation should take us closer to the "true" technique and composition effects. However, there is no reason to expect any particular direction - a pollution-increasing (a positive value) or pollutiondecreasing (a negative value) composition effect. Based on an idea that a switch towards energy- and resource-intensive products is driven by consumers (e.g., Brunel 2017; Hart 2018), one can expect (i) that a composition effect is pollution-increasing, (ii) that this effect will typically be underestimated because switches to, e.g., more powerful and heavier cars will not show up in the data, and (iii) that increasing disaggregation may lead towards capturing the "true" value of the technique and composition effects. From Table 5, the composition effect for $\mathrm{NO}_{\mathrm{x}}$ emissions, estimated at the two-digit level with the Laspeyres index, is $+2.7 \%$ (vs. $+5.8 \%$ ) and for VOCs emissions $+15.4 \%$ (vs. +20.3 $\%$ ). For $\mathrm{PM}_{10}$ emissions, the composition effect is negative, $-1.4 \%$ (vs. $+3.2 \%$ ), suggesting a shift towards cleaner goods in the mix of industries. Thus, with more aggregated data, the brown shift is smaller in magnitude, and, as in the case with $\mathrm{PM}_{10}$ emissions, the results of the decomposition analysis on the role of compositional changes may point to an opposite direction. Thus, the missed effects may either reinforce or counteract the effects found at the aggregate level.

Table 5 Decomposition analysis at the two-digit level, 2007-2017

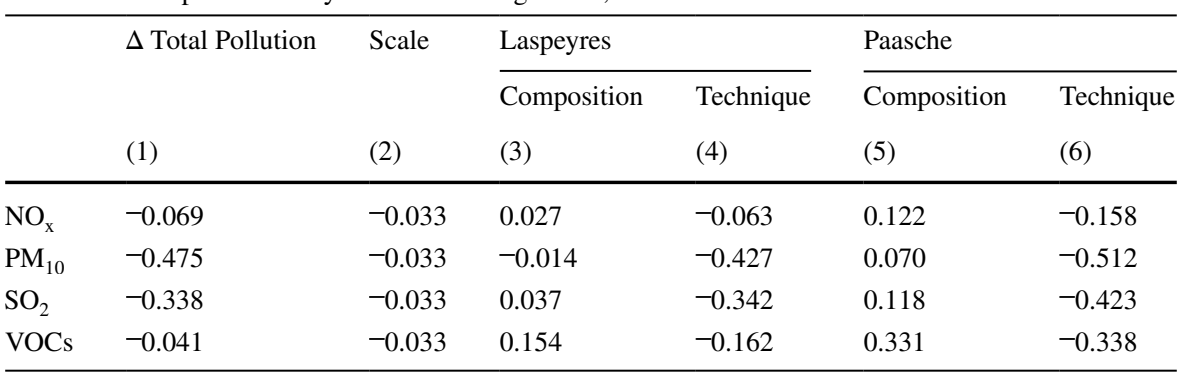

Table reports estimates from a decomposition of the change in air pollution intensity of the Swedish manufacturing sector between 2007 and 2017. The industries are defined as two-digit codes under the NACE Rev. 2 classification. Column 1 reports the percentage change in aggregate emissions from the manufacturing sector compared to emissions in the year 2007. The aggregate pollution is decomposed into the scale (column 2), composition and technique effects using the Laspeyres'-type index (columns 3 and 4) and the Paasche's-type index (columns 5 and 6). Each row reports estimates for a different air pollutant 
Regarding the composition effect, the brown shift shown in Figure 1 is clearly not driven by one or two specific industries. The pattern reflects a persistent tendency to move towards more polluting manufacturing goods. The brown shift in manufacturing started already in 2001 in the EU and after the financial crisis in China (Brunel 2017; Cole and Zhang 2019). Thus, the increasing specialisation towards "dirty" goods, captured in this paper, is part of a bigger picture - this supply shift away from cleaner industries extends across several states (advanced economies within the EU and China) and a longer period, from 2001 onwards. The brown shift appeared when additional and more stringent environmental policies were implemented in the EU.

Three additional tables show the results with alternative versions of the same dataset (Tables 10 and 11) or alternative data on pollution emissions and methods (Table 6). There is a reasonable concern that the results might be affected by the inclusion of the years around the financial crisis in the analysis. To address the issue, I re-run the decomposition for a shorter period-between 2010 and 2017. From Table 11, the decomposition method appears to be sensitive for the choice of the studied period: as the scale effect is large and positive $(+10 \%)$, the composition effect for $\mathrm{NO}_{\mathrm{x}}, \mathrm{PM}_{10}$ and $\mathrm{SO}_{2}$ estimated using the Laspeyres index changes its sign to the opposite. The alternative results in Table 10 are to check whether the choice of the deflator might have led to an underestimation of the role of the technique effect and a corresponding overestimation of the composition effect, or led to an overestimation of the importance of the computer industry for the overall clean-up in manufacturing (Tables 10, 11).

I also test whether the main results are sensitive to the source of pollution data. As the Swedish PRTR contains self-reported plant-level data from facilities that emit above certain thresholds, it does not include emissions from smaller polluters. To address these concerns, I employ data on manufacturing pollution emissions from the AEA and present the results in Table 6. The data is only available at the two-digit level, and it starts from the year 2008. With a higher level of aggregation, there are fewer zeroes in the sample, and I can use the log-mean Divisia index,

Table 6 Decomposition analysis using alternative methods and data sources, 2008-2017

\begin{tabular}{|c|c|c|c|c|c|c|}
\hline & \multicolumn{2}{|l|}{ Benchmark* } & \multicolumn{2}{|l|}{ AEA* $^{*}$} & \multicolumn{2}{|l|}{ AEA, LMDI } \\
\hline & $\begin{array}{l}\text { Composition } \\
\text { (1) }\end{array}$ & $\begin{array}{l}\text { Technique } \\
\text { (2) }\end{array}$ & $\begin{array}{l}\text { Composition } \\
\text { (3) }\end{array}$ & $\begin{array}{l}\text { Technique } \\
\text { (4) }\end{array}$ & $\begin{array}{l}\text { Composition } \\
\text { (5) }\end{array}$ & $\begin{array}{l}\text { Technique } \\
\text { (6) }\end{array}$ \\
\hline $\mathrm{SO}_{2}$ & 0.076 & -0.350 & -0.011 & -0.237 & 0.02 & -0.259 \\
\hline $\mathrm{NO}_{\mathrm{x}}$ & 0.044 & -0.059 & -0.003 & -0.145 & 0.02 & -0.161 \\
\hline $\mathrm{PM}_{10}$ & 0.024 & -0.185 & -0.015 & -0.366 & -0.002 & -0.379 \\
\hline VOCs & 0.240 & -0.210 & 0.132 & -0.38 & 0.25 & -0.398 \\
\hline
\end{tabular}

Notes: Table shows estimates from a decomposition of the change in air pollution intensity for the Swedish manufacturing sector between 2008 and 2017. Columns 1 and 2 present the benchmark results obtained as in Table 3 but for the period 2008-2017 due to data availability. Columns 3-6 show the results for the decomposition analysis using data on pollution emissions at two-digit level from the Air Environmental Accounts from Statistics Sweden. The results marked by * are obtained using the Laspeyres'-type index. The last two columns, 5 and 6, show the estimates from a decomposition using the logmean Divisia decomposition index 
which does not leave a residual term as the Laspeyres or Paasche index. ${ }^{16}$ As shown in Table 6, the main results - the importance of technique in the overall manufacturing abatement and the brown shift-persist regardless of the decomposition method and data source but the magnitude is different.

\section{Conclusions}

In this paper, I have shown that decomposition analysis with four-digit data on manufacturing production and actual emissions reveals a substantial shift in the composition of Swedish manufacturing towards pollution-intensive production, despite rapid increases in the pollution-efficiency of technology. Improvements in technology are presumably driven by increasingly stringent environmental regulations, regulations which might be expected to push patterns of production and consumption in the same (environmental-friendly) direction. I find the largest technique effect for $\mathrm{PM}_{10}$ and $\mathrm{SO}_{2}$ emissions -47 and $38 \%$ using the Laspeyres index and 51 and $42 \%$ using the Paasche index, respectively.

The findings suggest that in the absence of changes in scale and technique, $\mathrm{SO}_{2}$ emissions would increase by $7 \%$ and VOCs emissions would rise by as much as $20 \%$ compared to the level of the year 2007. Taking into account that similar patterns were observed in the EU manufacturing sector already at the beginning of the 2000s' (Brunel 2017) and in a more recent period in China (Cole and Zhang 2019), the results in this paper might indicate that the increasing specialisation towards more pollution-intensive production is a part of a larger shift, extending across several states.

The paper sheds light on heterogeneity within the manufacturing sector in Sweden. For the most pollution-intensive industries that account for more than $80 \%$ of the gross manufacturing air pollution emissions, the technique and composition effects differ both in magnitude and sign. They also vary across pollutants. For instance, for the paper and pulp industry, the technique effect is almost one-tenth of the value for the whole sector and plays a minor role in the reductions of $\mathrm{NO}_{\mathrm{x}}$ emissions. Being aware of heterogeneity within the manufacturing sector is important from a policy perspective but also for future research as it emphasizes the importance of data disaggregation. Employing more detailed data may lead towards capturing the "true" value of the technique and composition effects. I show that with more aggregated data, the brown shift is smaller in magnitude.

This study's major implication is that policy makers should take into account that manufacturing producers may shift to more dirty goods at the same time as reducing the emissions intensity of existing products. For Sweden, as for other countries within the EU, multiple ambitious goals such as improved energy efficiency, increased share of renewables in energy consumption and reduced air emissions in the nearest 10-25 years are on agenda. To achieve the targets, it is important to be aware of the strengths of the composition and technique effects to minimize the risk that an emission-reducing policy might

\footnotetext{
${ }^{16}$ For the decomposition of emissions with the LMDI, I use the formula for the index in its multiplicative form, i.e., the change in total emissions between year 0 and year $T$ equals to the product of changes in the scale, composition and technique between years 0 and $T$. For example, the technique effect is calculated as $\sum_{i} L\left(P_{i}^{T}, P_{i}^{0}\right) \ln \left(\frac{z_{i}^{T}}{z_{i}^{0}}\right)$ where $L(a, b)=\frac{(a-b)}{\ln a-\ln b}$.
} 
lead to countervailing changes in the mix of industries and goods. Thus, either the technique effect has to be even stronger, or compositional changes towards dirty goods should be prevented. For this, more research is needed to identify the sources of both brown shift and pollution-decreasing technique effect. If the latter is primarily due to, for instance, firms switching to another type of fuel, it might have a limited effect on the future cleanup as firms do not adopt new technologies. For the pollution-increasing composition effect, it is important to identify whether it is driven by the demand or supply side. If it occurs on the producers' side there is a need for even more stringent regulations on firms and their emissions.

\section{Appendix}

\section{Data: additional details}

For every pollutant, the Swedish Pollutant Release and Transfer Register (PRTR) contains data on its plant-level annual emissions. Data on pollution emissions from 431 manufacturing plants (191 manufacturing firms) is included in the analysis. For every facility, there is a name of the facility together with the firm's name and its Swedish id-number but it does not contain industry codes under the NACE Rev. 2 classification. I use the id-numbers to extract four-digit industry codes from the database Retriever that contains data on the majority of Swedish firms for the period 2010-2019. Using the four-digit codes, I keep only manufacturing facilities, i.e., facilities with four-digit codes within the range 10.11-33.20 under the NACE Rev. 2 classification. To merge the data on pollution emissions with output data from Statistics Sweden, I aggregate plant-level emissions to a four-digit level. The output data from Statistics Sweden does not always contain data for each four-digit sector separately. For some sectors, it reports data for a group of sectors for one or several years. To deal with it, I combine output for those affected sectors into larger groups (e.g., all sectors between 19.10 and 20.17 are combined into one group, 19.10-20.17). The data on pollution emissions is aggregated in the same way.

Table 7 Descriptive statistics

\begin{tabular}{llllll}
\hline Variables & $N$ & Mean & SD & Min & Max \\
\hline Value of output per 4-digit industry, bln SEK & 1738 & 10.14 & 25.80 & 0.0164 & 273.8 \\
Total value of output, bln SEK & 11 & 1603 & 80.86 & 1403 & 1721 \\
Industry's share in total output & 1738 & 0.00633 & 0.0161 & 0.0000105 & 0.170 \\
Emissions of $\mathrm{SO}_{2}$, tons & 1738 & 51.56 & 312.8 & 0 & 3826 \\
Emissions of $\mathrm{NO}_{\mathrm{x}}$, tons & 1738 & 132.5 & 877.6 & 0 & 11003 \\
Emissions of $\mathrm{VOCs}$, tons & 1738 & 166.1 & 1213 & 0 & 11681 \\
Emissions of $\mathrm{PM}_{10}$, tons & 1738 & 23.05 & 194.1 & 0 & 3585 \\
Emissions intensity, $\mathrm{SO}_{2}$, tons/bln SEK & 1738 & 1.885 & 10.91 & 0 & 132.4 \\
Emissions intensity, $\mathrm{NO}_{\mathrm{x}}$, tons/bln SEK & 1738 & 7.699 & 54.97 & 0 & 816.1 \\
Emissions intensity, $\mathrm{VOCs}_{\text {, tons/bln SEK }}$ & 1738 & 4.128 & 21.78 & 0 & 235.1 \\
Emissions intensity, $\mathrm{PM}_{10}$, tons/bln SEK & 1738 & 0.734 & 5.675 & 0 & 80.32 \\
\hline
\end{tabular}




\section{Additional results}

See Fig. 3 and Table 8.

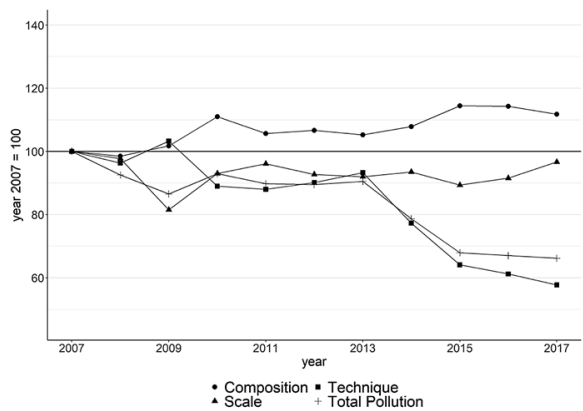

(a) $\mathrm{SO}_{2}$

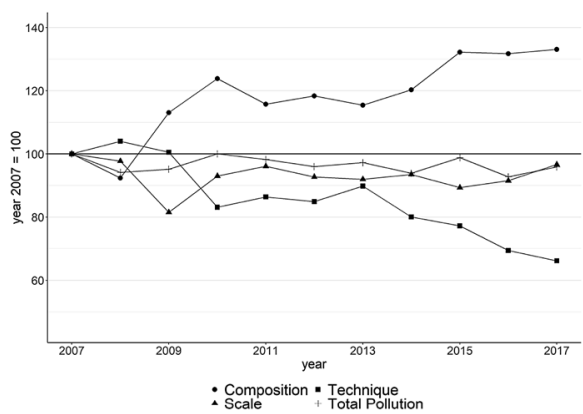

(c) VOCs

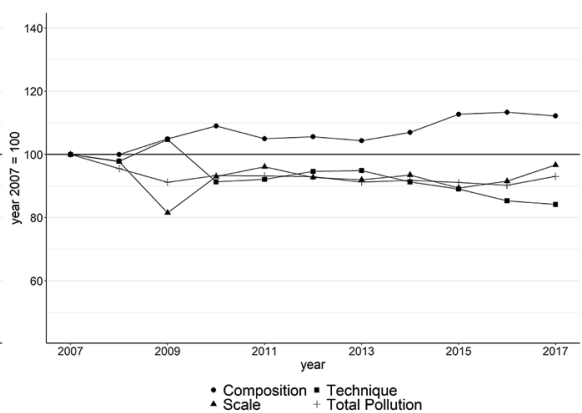

(b) $\mathrm{NO}_{\mathrm{x}}$

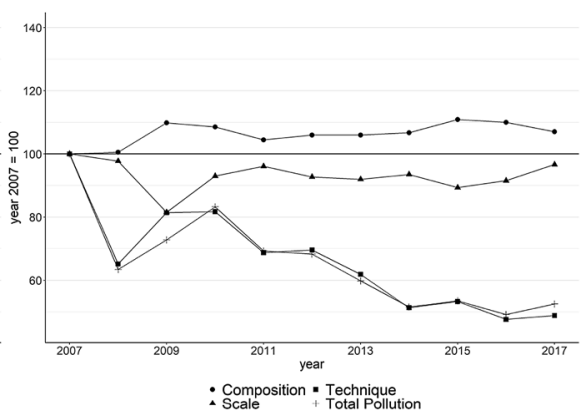

(d) $\mathrm{PM}_{10}$

Fig. 3 Decomposition of air pollution emissions from Swedish manufacturing, 2007-2017. Notes The technique effect is calculated by taking the percentage change in a Paasche's-type index as in Eq. (5). The composition effect is calculated as the difference between the change in the aggregate pollution, the scale effect and the technique effect. Values are normalized to 100 in 2007

Table 8 Decomposition of Swedish Manufacturing $\mathrm{CO}_{2}$ Emissions, 2007-2017

\begin{tabular}{|c|c|c|c|c|c|}
\hline \multirow[t]{2}{*}{$\Delta$ Total pollution } & \multirow[t]{2}{*}{ Scale } & \multicolumn{2}{|l|}{ Laspeyres } & \multicolumn{2}{|l|}{ Paasche } \\
\hline & & Composition & Technique & Composition & Technique \\
\hline (1) & (2) & (3) & (4) & (5) & (6) \\
\hline 0.041 & -0.033 & 0.070 & 0.005 & 0.147 & -0.073 \\
\hline
\end{tabular}

Table reports estimates from a decomposition of the change in $\mathrm{CO}_{2}$ emissions intensity of the Swedish manufacturing sector between 2007 and 2017. Data on $\mathrm{CO}_{2}$ emissions are obtained from the Swedish PRTR. The industries are defined as four-digit codes under the NACE Rev. 2 classification. Column 1 reports the percentage change in aggregate emissions from the manufacturing sector compared to the year 2007. The aggregate pollution is decomposed into the scale (column 2), composition and technique effects using the Laspeyres'-type index (columns 3 and 4) and the Paasche's-type index (columns 5 and $6)$. Each row reports estimates for a different air pollutant 


\section{Robustness checks}

See Tables 9, 10, 11.

Table 9 Decomposition analysis without pollution-intensive industries, 2007-2017

\begin{tabular}{|c|c|c|c|c|c|c|}
\hline & \multirow{2}{*}{$\begin{array}{l}\Delta \text { Total Pollution } \\
\text { (1) }\end{array}$} & \multirow{2}{*}{$\begin{array}{l}\text { Scale } \\
\text { (2) }\end{array}$} & \multicolumn{2}{|l|}{ Laspeyres } & \multicolumn{2}{|l|}{ Paasche } \\
\hline & & & $\begin{array}{l}\text { Composition } \\
\text { (3) }\end{array}$ & $\begin{array}{l}\text { Technique } \\
\text { (4) }\end{array}$ & $\begin{array}{l}\text { Composition } \\
\text { (5) }\end{array}$ & $\begin{array}{l}\text { Technique } \\
\text { (6) }\end{array}$ \\
\hline $\mathrm{NO}_{\mathrm{x}}$ & -0.214 & -0.036 & 0.167 & -0.345 & 0.255 & -0.433 \\
\hline $\mathrm{PM}_{10}$ & -0.600 & -0.096 & -0.124 & -0.380 & 0.025 & -0.528 \\
\hline $\mathrm{SO}_{2}$ & -0.146 & -0.029 & 0.351 & -0.468 & 0.395 & -0.512 \\
\hline VOCs & -0.241 & -0.097 & 0.049 & -0.193 & 0.075 & -0.219 \\
\hline
\end{tabular}

Table reports estimates from a decomposition of the change in air pollution intensity of the Swedish manufacturing sector between 2007 and 2017. The industries are defined as four-digit codes under the NACE Rev. 2 classification. The table reports the result of the decomposition analysis without five most pollution-intensive industries. The industries are excluded based on an average emission intensity for each pollutant. Column 1 reports the percentage change in aggregate emissions from the manufacturing sector compared to emissions in the year 2007. The aggregate pollution is decomposed into the scale (column 2), composition and technique effects using the Laspeyres'-type index (columns 3 and 4) and the Paasche's-type index (columns 5 and 6). Each row reports estimates for a different air pollutant. The removed four-digit industries are different for different pollutants

Table 10 Decomposition analysis using alternative samples, 2007-2017

\begin{tabular}{llllll}
\hline & \multicolumn{2}{l}{ Without Computers } & & \multicolumn{2}{l}{ Overall PPI } \\
\cline { 2 - 3 } \cline { 5 - 6 } & Composition & Technique & & Composition & Technique \\
& $(1)$ & $(2)$ & & $(3)$ & $(4)$ \\
\hline $\mathrm{NO}_{\mathrm{x}}$ & 0.026 & -0.094 & & 0.016 & -0.223 \\
$\mathrm{PM}_{10}$ & 0.000 & -0.473 & & -0.064 & -0.548 \\
$\mathrm{SO}_{2}$ & 0.039 & -0.375 & & -0.028 & -0.448 \\
$\mathrm{VOCs}$ & 0.172 & -0.211 & & 0.121 & -0.299 \\
\hline
\end{tabular}

Table shows estimates from a decomposition of the change in air pollution intensity for the Swedish manufacturing sector between 2007 and 2017. The industries are defined as four-digit codes under the NACE Rev. 2 classification. Columns 1 and 2 report the results for the sample without industry "Manufacture of computer, electronic and optical products" (26). In columns 3 and 4, the sample is similar to the benchmark but the output values are deflated using the overall PPI. Each row reports estimates for a different air pollutant. In all cases, the Laspeyres'-type index is used 
Table 11 Decomposition analysis with shorter sample, 2010-2017

\begin{tabular}{|c|c|c|c|c|c|c|}
\hline & \multirow{2}{*}{$\begin{array}{l}\Delta \text { Total pollution } \\
\text { (1) }\end{array}$} & \multirow{2}{*}{$\begin{array}{l}\text { Scale } \\
\text { (2) }\end{array}$} & \multicolumn{2}{|l|}{ Laspeyres } & \multicolumn{2}{|l|}{ Paasche } \\
\hline & & & $\begin{array}{l}\text { Composition } \\
\text { (3) }\end{array}$ & $\begin{array}{l}\text { Technique } \\
\text { (4) }\end{array}$ & $\begin{array}{l}\text { Composition } \\
\text { (5) }\end{array}$ & $\begin{array}{l}\text { Technique } \\
\text { (6) }\end{array}$ \\
\hline $\mathrm{NO}_{\mathrm{x}}$ & -0.003 & 0.103 & -0.022 & -0.084 & 0.105 & -0.211 \\
\hline $\mathrm{PM}_{10}$ & -0.369 & 0.103 & -0.084 & -0.388 & -0.014 & -0.458 \\
\hline $\mathrm{SO}_{2}$ & -0.288 & 0.103 & -0.015 & -0.377 & 0.063 & -0.455 \\
\hline VOCs & -0.041 & 0.103 & 0.130 & -0.274 & 0.341 & -0.485 \\
\hline
\end{tabular}

Table reports estimates from a decomposition of the change in air pollution intensity of the Swedish manufacturing sector between 2010 and 2017. The industries are defined as four-digit codes under the NACE Rev. 2 classification. Column 1 reports the percentage change in aggregate emissions from the manufacturing sector compared to the year 2007. The aggregate pollution is decomposed into the scale (column 2), composition and technique effects using the Laspeyres'-type index (columns 3 and 4) and the Paasche's-type index (columns 5 and 6). Each row reports estimates for a different air pollutant

\section{EU legislation implemented in Sweden}

- Directive 80/779/EEC on air quality limit values and guide values for sulphur dioxide and suspended particulates. Repealed by Council Directive 1999/30/EC.

- Directive $85 / 203 / \mathrm{EEC}$ on air quality standards for nitrogen dioxide. Repealed by Council Directive 1999/30/EC.

- In 1996, Integrated Pollution Prevention and Control (IPPC) Directive (96/61/ EC) set out the main principles for the permitting and control of installations based on an integrated approach and the application of so-called best available techniques (BAT), i.e., the most effective techniques taking into account environmental protection, costs and benefits. According to the IPPC directive, producers in pollution-intensive industries were obliged to apply for permission. The IPPC directive was transposed into the Swedish national law through the Swedish Environmental Code (Miljöbalken). Repealed by Directive (2010/75/EU) on industrial emissions. Following the Environmental Code, facilities with great environmental impact must have a license to operate but this requirement applies to a larger number of activities than were covered initially by the IPPC Directive. In particular, the permit requirement is applied to hazardous activities labelled as class A (e.g., large scale production of wood pulp or large scale production of pharmaceuticals, including intermediates) or B (e.g., facilities that produce glass, including fiberglass, with a melting rate of more than 20 tonnes per day or more than 5000 tonnes per calendar year). The activities of class $\mathrm{C}$ (e.g., industrial manufacture of briquettes of coal) require only a notification to the Environment Committee of the municipality before starting up. ${ }^{17}$

- The Air Quality Framework Directive (96/62/EC) set out the principles of ambient air quality monitoring, assessment and management. The directive was fol-

\footnotetext{
17 The classification of activities is regulated by the Environmentally Hazardous Activities and Health Protection Ordinance (1998:899) and its successor, the ordinance (2013:251), https://www.riksdagen.se/ sv/dokument-lagar/dokument/svensk-forfattningssamling/_sfs-2013-251/, viewed 07 April 2020.
} 
lowed by four daughter directives which detailed the limit values for specific pollutants. The directive was repealed by Directive 2008/50/EC.

- First Daughter Directive: Directive (1999/30/EC) limited values for sulphur dioxide, nitrogen dioxide and oxides of nitrogen, particulate matter and lead in ambient air. Repealed by Directive 2008/50/EC.

- Second Daughter Directive: Directive 2000/69/EC limited values for benzene and carbon monoxide in ambient air. Repealed by Directive 2008/50/EC.

- Third Daughter Directive: Directive 2002/3/EC related to ozone in ambient air. Repealed by Directive 2008/50/EC.

- Fourth Daughter Directive: Directive 2004/107/EC sets out limits of arsenic, cadmium, mercury, nickel and polycyclic aromatic hydrocarbons in ambient air.

- Directive (2001/81/EC) on national emissions ceilings (NEC). It set binding emission ceilings that each member state should achieve by 2010 . The directive covers four air pollutants: sulphur dioxide, nitrogen oxides, non-methane volatile organic compounds, and ammonia. The directive was revised and replaced by the new NEC directive in 2016 (2016/2284/EU).

- The large combustion plants (LCP) Directive (2001/80/EC) covered plants with a rated thermal capacity of at least 50 megawatts (MW) and set emission standards for both new and existing plants. The directive contained emission limit values for sulphur dioxide, nitrogen oxides and dust, varying according to the age and capacity of the plants, as well as the type of fuel burned. Repealed by Directive (2010/75/EU) on industrial emissions.

- Regulation 166/2006 on the European Pollutant Release and Transfer Register (E-PRTR) regulates creating a register that gives the public access to detailed information on the emissions and the off-site transfers of pollutants and waste from industrial facilities in all Member States and Iceland, Liechtenstein and Norway. The register contains data reported annually by some 30000 industrial facilities covering 65 economic activities across Europe.

- Directive (2008/50/EC) on ambient air quality and cleaner air for Europe. The Directive merges the existing air quality legislation into a single directive, except for the Fourth Daughter Directive, with no change of air quality objectives. The Directive introduces air quality objectives for $\mathrm{PM}_{2.5}$ (fine particles), including the limit value and exposure-related objectives that entered into force 2015. The permissible levels stipulated in the directive are the minimum values that EU states must strive to achieve, i.e., each country may introduce more demanding standards. The directive does not say anything about how the limit values should be achieved. But it does require that each member country takes proper actions when the requirements are not met.

- Directive (2010/75/EU) on industrial emissions (IED) establishes the main principles for permitting and control of large industrial installations based on an integrated approach and the application of BAT. All facilities undertaking the industrial activities listed in Annex I of the IED are required to operate 
in accordance with a permit. The permit is issued by the authorities in the Member States. This permit should contain conditions set following the principles and provisions of the IED. One significant change, compared with the former IPPC directive, is that emission limit values that can be achieved using the BATs become binding values. These values are introduced into the Swedish Industrial Emissions Ordinance (Industriutsläppsförordning (2013:250)). The IED replaced several previously existing directives (including, in particular, the IPPC Directive). It entered into force in January 2011 and had to be transposed by the Member States by January 2013. For what types of industrial activities there is a requirement to obtain a permit is transposed into the Swedish legislation through Miljöprövningsförordning (2013:251).

- Directive (2015/2193/EU) on medium combustion plants (MCPD) regulates emissions of sulphur dioxide, nitrogen oxides and dust from the combustion of fuels in plants with a rated thermal input between 1 and $50 \mathrm{MW}$ thermal.

- A new National Emissions Ceilings (NEC) Directive (2016/2284/EU) entered into force on 31 December 2016. It replaced Directive (2001/81/EC) and sets 2020 and 2030 emission reduction commitments for five main air pollutants: $\mathrm{NO}_{\mathrm{x}}, \mathrm{VOCs}, \mathrm{SO}_{2}, \mathrm{NH}_{3}$ and $\mathrm{PM}_{2.5}$. It also ensures that the emission ceilings for 2010 set in the earlier directive remain applicable for Member States until the end of 2019 .

\section{Other taxes and charges aiming for clean production and installation of pollu- tion prevention technologies ${ }^{18}$}

- In 1991, a carbon tax was introduced. It mainly affects transport. Industry and agriculture receive a lower $\mathrm{CO}_{2}$ tax rate.

- In 1991, a sulphur tax for electricity and heat production was introduced. The tax is based on the sulphur content of fuels during combustion and is paid depending on the actual emission of $\mathrm{SO}_{2}$.

- Starting from the year 1992, there is a Swedish charge on $\mathrm{NO}_{\mathrm{x}}$. The purpose is to reduce emissions $\mathrm{NO}_{\mathrm{x}}$ from combustion plants that produce energy. The threshold for the charge had been gradually lowered. It started from $50 \mathrm{GWh}$ per year from a combustion plant in the year 1992 to less than $10 \mathrm{GWh}$ per year after 1997.

- In 2011, an energy tax on fossil heating fuels was introduced. The amount to pay depends on the energy content.

\section{Major air pollutants}

See Table 12.

\footnotetext{
18 UN Environment Program, Sweden-Air Quality Policies, https://www.unenvironment.org/resources/ policy-and-strategy/air-quality-policies-sweden, viewed 10 January 2020.
} 


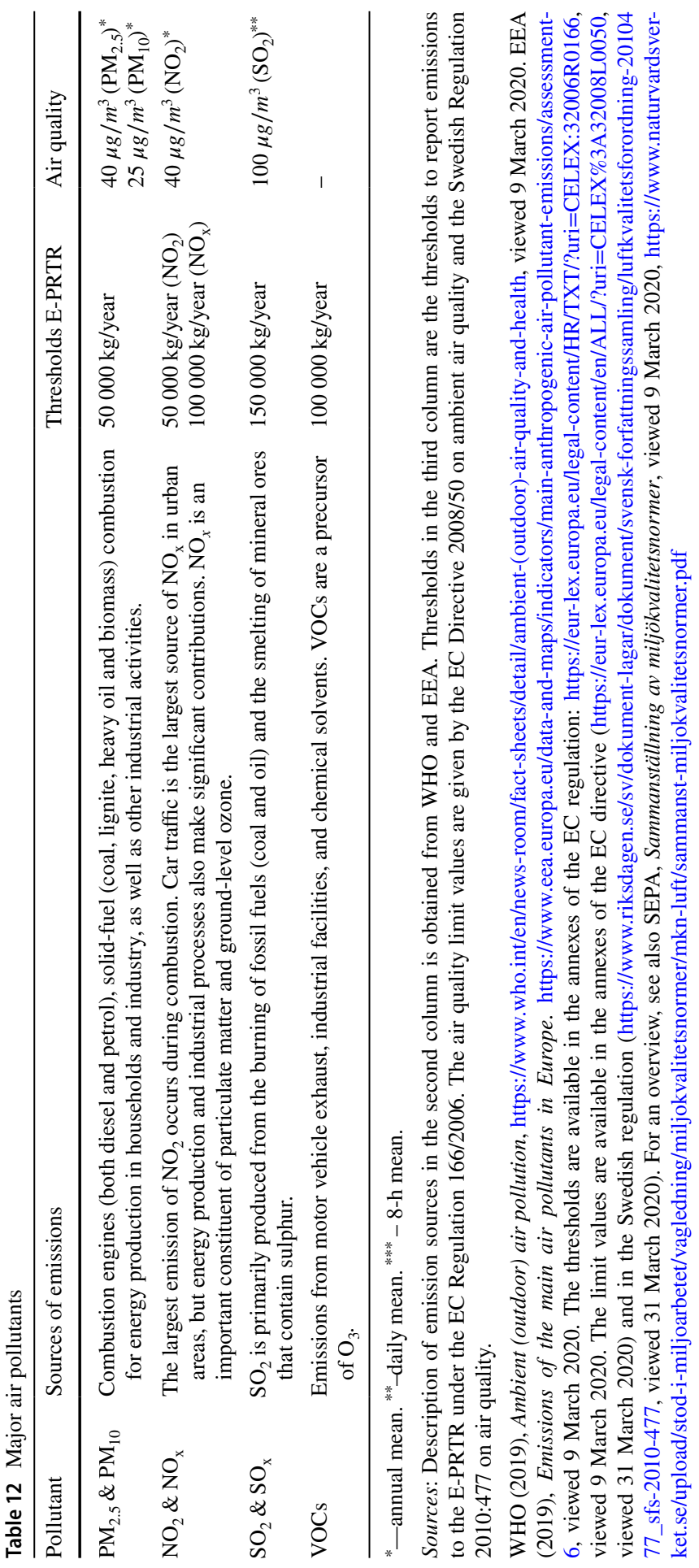


Funding Open access funding provided by Swedish University of Agricultural Sciences.

Open Access This article is licensed under a Creative Commons Attribution 4.0 International License, which permits use, sharing, adaptation, distribution and reproduction in any medium or format, as long as you give appropriate credit to the original author(s) and the source, provide a link to the Creative Commons licence, and indicate if changes were made. The images or other third party material in this article are included in the article's Creative Commons licence, unless indicated otherwise in a credit line to the material. If material is not included in the article's Creative Commons licence and your intended use is not permitted by statutory regulation or exceeds the permitted use, you will need to obtain permission directly from the copyright holder. To view a copy of this licence, visit http://creativecommons.org/licen ses/by/4.0/.

\section{References}

Ang BW (2004) Decomposition analysis for policymaking in energy: which is the preferred method? Energy Policy 32(9):1131-1139

Åström S, Yaramenka K, Mawdsley I, Danielsson H, Grennfelt P, Gerner A, Ekvall T, Ahlgren EO (2017) The impact of Swedish SO2 policy instruments on SO2 emissions 1990-2012. Environ Sci Policy 77:32-39

Barrett S (1994) Strategic environmental policy and international trade. J Public Econ 54(3):325-338

Barrows G, Ollivier H (2018) Cleaner firms or cleaner products? How product mix shapes emission intensity from manufacturing. J Environ Econ Manag 88:134-158

de Boer P, Rodrigues JF (2020) Decomposition analysis: when to use which method? Econ Syst Res 32(1):1-28

Brunel C (2017) Pollution offshoring and emission reductions in EU and US manufacturing. Environ Resour Econ 68(3):621-641

Brunel C, Levinson A (2021) Globalization and greenhouse gas emissions: evidence from the United States. NBER Working Paper, no. w28372

Cave LA, Blomquist GC (2008) Environmental policy in the European Union: fostering the development of pollution havens? Ecol Econ 65(2):253-261

Cherniwchan J, Copeland BR, Taylor MS (2017) Trade and the environment: new methods, measurements, and results. Ann Rev Econ 9:59-85

Cole MA, Zhang L (2019) The clean-up of Chinese manufacturing: examining the role played by changing techniques of production. Econ Lett 180:11-14

Copeland BR, Taylor MS (1994) North-South trade and the environment. Q J Econ 109(3):755-787

Copeland BR, Taylor MS (2005) Trade and the environment: theory and evidence. Princeton University Press, Princeton

Ellerman $\mathrm{AD}$, McGuinness $\mathrm{M}$ (2008) $\mathrm{CO}_{2}$ abatement in the UK power sector: evidence from the EU ETS trial period. MIT-Center for Energy and Environmental Policy Research Working paper, vol. 0810

Gamper-Rabindran S (2009) The Clean Air Act and volatile organic compounds: Did plants reduce their health-indexed air emissions or shift their emissions into other media?, Manuscript, available at https://www.maxwell.syr.edu/uploadedfiles/cpr/events/cpr_seminar_series/previous_seminars/rabin dran.pdf, Accessed 1 June 2021

Gibson M (2019) Regulation-induced pollution substitution. Rev Econ Stat 101(5):827-840

González PF, Landajo M, Presno MJ (2014) Tracking European Union $\mathrm{CO}_{2}$ emissions through LMDI (logarithmic-mean Divisia index) decomposition. The activity revaluation approach. Energy 73:741-750

Graff Zivin J, Neidell M (2013) Environment, health, and human capital. J Econ Lit 51(3):689-730

Greaker M (2003) Strategic environmental policy; eco-dumping or a green strategy? J Environ Econ Manag 45(3):692-707

Greenstone M (2003) Estimating regulation-induced substitution: the effect of the Clean Air Act on water and ground pollution. Am Econ Rev 93(2):442-448

Grether J-M, Mathys NA, de Melo J (2009) Scale, technique and composition effects in manufacturing SO2 emissions. Environ Resour Econ 43(2):257-274

Grossman GM, Krueger AB (1993). In: Garber PM (ed) The Mexico-US free trade agreement. MIT Press, Environmental impacts of a North American free trade agreement, Cambridge, pp 13-56 
Hart R (2018) Rebound, directed technological change, and aggregate demand for energy. J Environ Econ Manag 89:218-234

Hoekstra R, Van den Bergh JC (2003) Comparing structural decomposition analysis and index. Energy Econ 25(1):39-64

Kahn ME (2003) The geography of US pollution intensive trade: evidence from 1958 to 1994. Reg Sci Urban Econ 33(4):383-400

LaPlue LD, Erickson CA (2020) Outsourcing, trade, technology, and greenhouse gas emissions. Environ Econ Policy Stud 22(2):217-245

Levinson A (2009) Technology, international trade, and pollution from US manufacturing. Am Econ Rev 99(5):2177-2192

Levinson A (2015) A direct estimate of the technique effect: changes in the pollution intensity of US manufacturing, 1990-2008. J Assoc Environ Resour Econ 2(1):43-56

Levinson A, Taylor MS (2008) Unmasking the pollution haven effect. Int Econ Rev 49(1):223-254

Löfgren Å, Muller A (2010) Swedish $\mathrm{CO}_{2}$ emissions 1993-2006: an application of decomposition analysis and some methodological insights. Environ Resour Econ 47(2):221-239

Martin LA (2011) Energy efficiency gains from trade: greenhouse gas emissions and India's manufacturing sector, Manuscript, available at https://arefiles.ucdavis.edu/uploads/filer_public/2014/03/27/ martin-energy-efficiencynov.pdf

Millock K, Nauges C (2006) Ex post evaluation of an earmarked tax on air pollution. Land Econ 82(1):68-84

Miravete EJ, Moral MJ, Thurk J (2018) Fuel taxation, emissions policy, and competitive advantage in the diffusion of European diesel automobiles. RAND J Econ 49(3):504-540

Najjar N, Cherniwchan J (2020) Environmental regulations and the clean-up of manufacturing: plantlevel evidence. Rev Econ Stat 1:1-45

Naturvårdsverket, (2015) Historiska och framtida utsläpp av luftföroreningar i Sverige: Tren- der och analyser. Naturvårdsverket, Stockholm

Rottner E, von Graevenitz K (2021) What drives carbon emissions in german manufacturing: scale, technique or composition?. ZEW-centre for European economic research discussion paper, no. 21-027

Shapiro JS, Walker R (2018) Why is pollution from US manufacturing declining? The roles of environmental regulation, productivity, and trade. Am Econ Rev 108(12):3814-3854

Skårman T, Danielsson H, Mawdsley I, Hansson K (2019) Evaluation of thresholds for capacities and pollutants according to the protocol on PRTRs: case-study for the Nordic countries

Sterner T, Turnheim B (2009) Innovation and diffusion of environmental technology: industrial NOx abatement in Sweden under refunded emission payments. Ecol Econ 68(12):2996-3006

Tillväxtverket, (2018) Industrins tillväxt och konkurrenskraft: Industrins utveckling 2011-2016 i företag med 1-499 anställda. Tillväxtverket, Stockholm

Ulph A, Ulph D (1996) Trade, strategic innovation and strategic environmental policy-a general analysis. Springer, Environmental policy and market structure, Berlin, pp 181-208

Wagner UJ, Muûls M, Martin R, Colmer J (2014) The causal effects of the European Union Emissions Trading Scheme: evidence from French manufacturing plants, Manuscript, available at http://cites eerx.ist.psu.edu/viewdoc/download?doi=10.1.1.642.888\&rep=rep1\&type=pdf, Accessed 01 June 2021

WHO (2018) Ambient (outdoor) air pollution, https://www.who.int/en/news-room/fact-sheets/detail/ ambient-(outdoor)-air-quality-and-health Accessed 03 Sept 2020

Publisher's Note Springer Nature remains neutral with regard to jurisdictional claims in published maps and institutional affiliations. 